\title{
Article \\ Gender Differences in Intra-Household Financial Decision-Making: An Application of Coarsened Exact Matching
}

\author{
Frederik Booysen ${ }^{1}$ iD and Sevias Guvuriro ${ }^{2, *}$ (D) \\ 1 School of Economics and Finance, University of the Witwatersrand, Johannesburg 2000, South Africa; \\ frederik.booysen@wits.ac.za \\ 2 Department of Economics and Finance, University of the Free State, Bloemfontein 9301, South Africa \\ * Correspondence: guvuriros@ufs.ac.za; Tel.: +27-51-401-9196
}

Citation: Booysen, Frederik, and Sevias Guvuriro. 2021. Gender Differences in Intra-Household Financial Decision-Making: An Application of Coarsened Exact Matching. Journal of Risk and Financial Management 14: 469. https:// doi.org/10.3390/jrfm14100469

Academic Editor: Mark Harris

Received: 29 June 2021

Accepted: 6 September 2021

Published: 6 October 2021

Publisher's Note: MDPI stays neutral with regard to jurisdictional claims in published maps and institutional affiliations.

Copyright: (c) 2021 by the authors. Licensee MDPI, Basel, Switzerland. This article is an open access article distributed under the terms and conditions of the Creative Commons Attribution (CC BY) license (https:// creativecommons.org/licenses/by/ $4.0 /)$.

\begin{abstract}
Most studies that explore collective models of intra-household decision-making use economic outcomes such as human capital, earnings, assets, and relative income shares as proxies of the relative distribution of bargaining power. These studies, however, fail to incorporate important measures of control over and management of the economic resources within households. In the current study, a direct measure of financial decision-making power within the household is used to directly assess the distribution of bargaining power. Coarsened exact matching, an identification strategy not yet applied in studies of this nature, is applied to couple-level observational data from South Africa's longitudinal National Income Dynamics Study. The influence of gender differences in intra-household decision-making on resource allocations to per capita household expenditure is assessed. In the case of greater financial decision-making power in couples being assigned to wives rather than husbands, per capita household expenditure on education increases significantly. The empowerment of women with financial decision-making power therefore holds the promise of realizing the benefits of investments in human capital.
\end{abstract}

Keywords: gender; intra-household decision-making; coarsened exact matching; household expenditure; resource allocation; South Africa

\section{Introduction}

Today, there is relatively substantial empirical support in economics for collective models of intra-household decision-making, models that provide a useful framework for an analysis of gender relations and their implications for resource allocations within couples and households (Baland and Ziparo 2018; Ambler et al. 2021). In these models, so-called distributional factors direct the allocation of resources (Doss 2013; Bourguignon et al. 2009; Himmelweit et al. 2013; Browning et al. 2014). Examples of distributional factors, also called "derivatives" of the sharing rule (Himmelweit et al. 2013), include relative ages, relative education or human capital, individual incomes, social norms, traditional roles, and institutional variables, such as legal and welfare rules affecting the cost of marriage breakdown (Maitra and Ray 2006; Bourguignon et al. 2009; Himmelweit et al. 2013; Bertocchi et al. 2014; Browning et al. 2014).

A commonly used identification strategy for testing the collective model empirically is to employ household survey data to assess how various distributional factors are related to expenditure patterns. In developing countries, the gender-based distribution of resources within couples and households has been shown to have positive and significant impacts on welfare-enhancing household expenditure. Improvements in women's economic bargaining power have been reported to translate into greater expenditure on food (Schmeer 2005; Gummarson and Schneider 2013; Opata et al. 2020) and education (Quisumbing and Maluccio 2003), and lower expenditure on alcohol and cigarettes (Gummarson and Schneider 2013; Opata et al. 2020). Menon et al. (2018) also noted that, when women exerted greater bargaining power, non-moderate consumption of vices such as alcohol 
is prevented. In developed and transition economies, however, the results point to both positive and negative impacts. Canadian households, for example, spent more on childcare (Phipps and Burton 1998), yet less on food consumed in the home and more on women's clothing (Browning and Chiappori 1998). Advancing women economically in Bulgarian households saw expenditure on food and children's clothing decline but witnessed an increase in expenditure on children's education (Felkey 2013). Greater bargaining power among Iranian women raised expenditure on education and health and decreased the budget share of tobacco consumption (Basu and Maitra 2020).

These studies generally use economic outcomes such as human capital, earnings, assets, and, in particular, relative income shares or differences in income between spouses as proxies of the relative distribution of bargaining power (Dosman and Adamowicz 2006). However, these studies, with the exception of Schmeer (2005), failed to incorporate into the analysis measures of control over and management of economic resources, or, as Katz (1997) put it, treated individuals symmetrically in regards to voice, including the ability to enter into the bargaining process. Broadly speaking, in terms of gender balance theory, this factor-defined here as financial decision-making, which at a higher level relates to both agency (Kabeer 1999; Iversen 2003) and autonomy (Vaz et al. 2016) - has an important role in leveraging greater power over household resources and, hence, influencing resource allocations (Blumberg and Coleman 1989).

In this paper, therefore, financial decision-making power that directly relates to economic bargaining power is treated as a higher-level distributional factor in exploring intra-household resource allocations in South African couples. In terms of empirical approach, use is made of coarsened exact matching, an identification strategy not yet applied in studies of this nature. Enhancing women's financial decision-making power is associated with higher monthly per capita household expenditure on some family-type public goods, in particular, education. Robustness checks using Mahalanobis distance matching and propensity score matching show that the result for education remains statistically significant.

The remaining part of the paper is structured as follows. Section 2 describes how the couple-level data were constructed, provides information on the financial decision-making question posed to respondents, and summarizes the treatment and control groups in the study. Section 3 outlines the empirical strategy adopted in the paper, while Section 4 presents the results and discussion. Section 5 concludes.

\section{Data}

Between 2008 and 2018, over the course of five survey rounds, South Africa's National Income Dynamics Study (NIDS) collected information on the financial decision-making roles of adult household members, on monthly household expenditure, and on a range of socio-demographic and economic characteristics of household members and households.

The couple-level data employed in this study were constructed as follows. On the household roster, it was recorded whether the specific adult was married to or lived with their partner. If so, the spouse's or partner's person code was recorded, but only if the person's name appeared on the household roster. ${ }^{1}$ In this way, female spouses or partners were linked to their male counterparts, with each observation in the pooled data representing one of a total of 9929 couples. For each couple, the individual-level characteristics were represented by two sets of variables, one for female and one for male spouses and partners. As no information was available on decision-making for non-resident household members, the sub-sample was restricted to co-resident couples. Furthermore, to ensure a more direct methodological link with household expenditure, the sample was restricted to couples including both a resident household head and the respondent to the expenditure module of the survey.

The survey asked the following question in regards to financial decision-making: "who makes decisions about day-to-day household expenditures?" Responses are recorded as "main decision-maker" or "if joint, who is the second decision maker?" In each case, the relevant person's personal identifier (pcode) was recorded on the questionnaire. Based on 
this information, a categorical variable, "decision-making power", was constructed that draws a distinction between none, joint, and main decision-makers. This classification was based on both self-identification (i.e., identifying yourself as a joint or main decisionmaker or not involved in decision-making) and the responses of other adult household members (i.e., others identifying the relevant person as a joint or main decision-maker or as a non-decision-maker). ${ }^{2}$

The analysis focused on estimating average treatment effects on the treated for a decision-making status treatment, constructed based on a comparison between spouses' and their partners' decision-making power (Table 1). The comparison was between couples in which the wife has more financial decision-making power compared to the husband (treatment- $\mathrm{C}$ and $\mathrm{F}$ in Table $1 ; n=4132$ ) and couples in which the husband has more financial decision-making power compared to the wife (control- $\mathrm{G}$ and $\mathrm{H}$ in Table 1; $n=3466$ ). The listwise deletion of covariates required in CEM (see empirical strategy) saw the analytical sample of 7598 reduced by $1.1 \%$ to 7511 .

Table 1. Treatment and comparison group—decision-making power.

\begin{tabular}{ccccc}
\hline & & \multicolumn{2}{c}{ Husband's Decision-Making Power } \\
\cline { 3 - 5 } & & None & Joint & Main \\
\hline \multirow{2}{*}{$\begin{array}{c}\text { Wife's } \\
\text { Necision-making }\end{array}$} & A & $\mathrm{D}$ & $\mathrm{G}$ \\
power & Joint & {$[n=111]$} & {$[n=29]$} & {$[n=238]$} \\
& & $\mathrm{B}$ & $\mathrm{E}$ & $\mathrm{H}$ \\
& Main & {$[n=123]$} & {$[n=1972]$} & {$[n=3228]$} \\
& & $\mathrm{C}$ & $\mathrm{F}$ & $\mathrm{I}$ \\
& & {$[n=650]$} & {$[n=3482]$} & {$[n=96]$} \\
\hline
\end{tabular}

\section{Empirical Strategy}

Where studies are characterized by selection, matching methods are used to estimate treatment effects using observational data (Baser 2006). In this study, we employed coarsened exact matching (CEM) (Blackwell et al. 2010; Iacus et al. 2012), with financial decision-making power designated as the treatment. Given a sample of $n$ couples randomly drawn from a population of $N$ couples, where $n \leq N$, for couple $i$ we denoted $T_{i}$ as an indicator variable with value $T_{i}=1$ if couple $i$ had a wife whose financial decision-making power was greater than that of the husband (and so, that couple was a member of the "treated" group), and $T_{i}=0$ if the wife had less financial decision-making power than the husband (and so, that couple was, therefore, a member of the "control" group). The outcome variable (in this study, per capita household expenditure of a given expenditure category) was denoted $Y$, where $Y_{i}(0)$ was the potential outcome for couple $i$ if the couple did not receive treatment (and, thus, was in the "control group"), and $Y_{i}(1)$ was the potential outcome if the (same) couple received treatment. So, for each observed couple the observed outcome was $Y_{i}=T_{i} Y_{i}(1)+\left(1-T_{i}\right) Y_{i}(0) . Y_{i}(0)$ was unobserved if couple $i$ received treatment, and $Y_{i}(1)$ was unobserved if couple $i$ did not receive treatment.

Matching estimators such as these controls for pre-treatment covariates in order to compensate for what Blackwell et al. (2010, p. 1) and Iacus et al. (2012, p. 3) called the "observational data problem", i.e., where the treated and control groups of couples are not necessarily identical before treatment. So, $X=\left(X_{1}, X_{2}, \ldots, X_{k}\right)$ is a $k$-dimensional data set, where each $X_{j}$ is a column vector of observed values of pre-treatment variable $j$ for the $n$ sample observations (drawn from a population of size N) (Blackwell et al. 2010; Iacus et al. 2012); that is, $X=\left[X_{i j, i=1, \ldots, n, j=1, \ldots, k}\right]$. The treatment effect (TE) for couple $i, T E_{i}=Y_{i}(1)-Y_{i}(0)$, is, of course, unobserved. Blackwell et al. (2010) and Iacus et al. (2012) suggested that one must focus on the sample average treatment effect on the treated (SATT), where:

$$
S A T T=\frac{1}{n_{T}} \sum_{i \in T} T E_{i}
$$


where $n_{T}=\sum_{i=1}^{n} T_{i}$ and $T=\left\{1 \leq i \leq n: T_{i}=1\right\}$. Blackwell et al. (2010) and Iacus et al. (2012) also assumed that treatment assignment was ignorable conditional on a $k$ dimensional data set, $X$, that is, the "no unmeasured confounders" or no "omitted variables" assumption. This assumption is formally presented as $P(T \mid X, Y(0), Y(1))=P(T \mid X)$, meaning that treatment assignment is independent of the potential outcomes.

CEM, as outlined above, comprises four basic steps: first, the covariates are coarsened; second, exact matching is implemented with the coarsened data; third, unmatched units in bins that do not contain units of the opposite exposure status, i.e., treatment or control, are eliminated; finally, SATT is estimated using the matched dataset (Ripollone et al. 2020). We now, in turn, discuss our approach to each step.

The matching algorithm included six covariates. Four related to so-called "couple differentials", while one was a household characteristic, namely, real per capita household income, measured in South African rands (ZAR, or simply, R). The sixth covariate was marital status. The differentials included differences between spouses and partners in age, years of education, income (ZAR, or simply, R), and employment status. The employment status variable drew a distinction between spouses and partners both being unemployed $[=1]$, only the husband working [=2], only the wife working [=3], and spouses and partners both being employed [=4]. This approach, i.e., the use of relative differences within couples, is informed by gender balance theory and the principle of heterogamy central to cooperative bargaining models of intra-household decision-making. Together, these factors were considered lower-level distributional factors entering into the matching model as determinants of decision-making power, which was defined as a higher-level distributional factor impacting more directly on resource allocations. For the purposes of coarsening covariates into substantively meaningful groups, the marital and employment status variables were retained as such, while the five other covariates were coarsened by adopting the following approach. Differentials in age and years of education were collapsed into three categories, representing couples in which the wife was older or more educated than her partner [=1], couples in which age and years of education were identical [=2], and couples in which the husband was older or more educated than his partner $[=3]$. Differentials in individual income were collapsed into four categories, namely, where incomes were equal but zero [=1], incomes were equal but not zero [=2], husband's income exceeded wife's income [=3], and wife's income exceeded husband's income [=4]. Real per capita household income was collapsed into five equally distributed income quintiles. CEM was then implemented with the aid of the cem and imb routines in Stata (Blackwell et al. 2010).

Given the right-censoring of expenditure data, the model used to estimate the SATT for each expenditure category was a Tobit regression model. The outcome measures were specific categories of real per capita household expenditure. The specific focus was on "family-type" public goods. Mok et al. (2011) and Himmelweit et al. (2013) considered family public goods as goods that can be shared within the family, while Felkey (2013) classified household public goods as those that give utility to all household members. Typical of such categories are water, heat, electricity, furniture, and car-related and transport expenses (Couprie et al. 2010). In addition, expenses on food (Gan and Vernon 2003) and on household members' education, health, insurance, and clothing (Suen et al. 2003) all constitute family-type public goods. All in all, ten expenditure categories were analyzed, i.e., food, non-food, education, healthcare, utilities, insurance, transport, clothing, household items, and personal items. The Tobit regression model was adjusted for three covariates, namely, the dependency ratio, quintiles of real per capita household income, and survey round. We report the unadjusted and unmatched results next to the matched and adjusted results (Table 5).

The choice of coarsened exact matching (CEM) over other matching methods was informed by a number of considerations. CEM, which is a matching method of the Monotonic Imbalance Bounding (MIB) class, bounds the maximum imbalance through an ex ante choice, rather than only discovering the ideal balance through a laborious (and sometimes 
arbitrary) process of checking balance ex post, tweaking the matching, and reestimating the outcome model. CEM also meets the congruence principle, with the data space and analysis space being the same, and reduces model dependence (Blackwell et al. 2010). Studies with both real and simulated data, moreover, have shown that CEM is superior to other matching methods in regards to achieving the best balance (Fullerton et al. 2016; Iacus et al. 2012; King and Nielsen 2019; Ripollone et al. 2020). Furthermore, CEM is considered most appropriate to use when the covariates include both continuous and discrete variables as well as so-called mixed variables, i.e., continuous variables with natural breakpoints (King and Nielsen 2019), such as is the case with the various couple differentials. CEM is also more appropriate when it is only necessary to control for relatively few $(<10)$ strong confounders (Ripollone et al. 2020). Finally, CEM also allows one to control for other important predictors of household expenditure when estimating SATTs.

In line with good practice, and in order to assess the robustness of our results, we estimated corresponding treatment effects on the treated (ATTs) with the aid of both Mahalanobis distance matching (MDM) (Stuart 2010) and propensity score matching (PSM) (Pan and Bai 2018) using Stata's psmatch2 (Leuven and Sianesi 2003) and teffects psmatch (StataCorp 2021). These results, estimated with OLS models, are reported in Appendix A.

\section{Results and Discussion}

\subsection{Couple and Household Characteristics}

The descriptive statistics in Table 2 show that wives were, on average, four years younger than husbands; wives' years of education were, on average, one sixth of a year more than husbands'; and wives' total incomes were, on average, R2671 lower than that of husbands. About three quarters of the couples were formally or traditionally married, with the balance described as "living together". When looking at employment differences between partners in a couple, the cases of "both employed", "only husband employed", and "only wife employed" had approximately one third share each. In about $10 \%$ of couples, only the wife was employed. The real per capita household income, household size, and dependency ratio for the households in which these couples lived were approximately R3366, 4.69, and 0.35, respectively.

Table 2. Partner and household characteristics.

\begin{tabular}{|c|c|c|c|c|c|c|c|c|c|}
\hline \multirow[b]{2}{*}{ Variable } & \multicolumn{3}{|c|}{ Wife } & \multicolumn{3}{|c|}{ Husband } & \multicolumn{3}{|c|}{ Difference } \\
\hline & M or $\%$ & SE & $n$ & M or $\%$ & SE & $n$ & M or $\%$ & SE & $n$ \\
\hline \multicolumn{10}{|c|}{ A. Partner characteristics } \\
\hline Age (years) & 45.19 & 0.13 & 9927 & 49.50 & 0.14 & 9928 & -4.31 & 0.06 & 9926 \\
\hline Married & 0.76 & 0.00 & 9929 & 0.76 & 0.00 & 9929 & & & \\
\hline Education (years) & 8.19 & 0.04 & 9913 & 8.02 & 0.4 & 9895 & 0.16 & 0.03 & 9881 \\
\hline Income & 3061.47 & 278.04 & 9929 & 5732.88 & 229.55 & 9929 & -2671.40 & 349.13 & 9929 \\
\hline \multicolumn{10}{|l|}{ Employed difference: } \\
\hline Both unemployed & & & & & & & 28.52 & & \\
\hline Only husband employed & & & & & & & 31.76 & & \\
\hline Only wife employed & & & & & & & 9.77 & & \\
\hline Both employed & & & & & & & 29.94 & & \\
\hline \multicolumn{10}{|c|}{ B. Household characteristics } \\
\hline Per capita household income & & & & & & & 3366.37 & 100.07 & 9929 \\
\hline Household size & & & & & & & 4.69 & 0.02 & 9929 \\
\hline Dependency ratio & & & & & & & 0.35 & 0.00 & 9929 \\
\hline
\end{tabular}




\subsection{Household Expenditure}

Table 3 reports mean monthly real per capita household expenditure and expenditure shares for each of the ten categories of expenditure for the full sample. Non-food expenditure, which is the balance of total and food expenditure, had a share of $44 \%$ and a mean of R1439. When disaggregating the expenditures, food (R473) had the highest mean value, followed by personal items (R267) and then transport (R263). For the remaining categories, expenditure ranged from R75 (education) to R144 (utilities), except for clothing, which was lowest, at R59. In terms of budget shares, couples allocated just more than one third of their resources to food. ${ }^{3}$

Table 3. Monthly per capita household expenditure and expenditure shares.

\begin{tabular}{cccc}
\hline Expenditure Category & ZAR & Share (\%) & Sample $(n)$ \\
\hline \multirow{2}{*}{ Food } & 473.65 & 0.34 & \\
& $(5.52)$ & $(0.00)$ & 9841 \\
Non-food & 1439.81 & 0.44 & \\
& $(37.23)$ & $(0.00)$ & 9841 \\
Education & 75.28 & 0.02 & \\
& $(4.63)$ & $(0.00)$ & 9519 \\
Healthcare & 115.49 & 0.02 & 9387 \\
Utilities & $(4.89)$ & $(0.00)$ & \\
Insurance & 144.95 & 0.06 & 9128 \\
& $(3.30)$ & $(0.00)$ & \\
Transport & 114.30 & 0.04 & \\
& $(5.28)$ & $(0.00)$ & 9291 \\
Clothing & 263.18 & 0.06 & \\
& $(8.39)$ & $(0.00)$ & 9538 \\
Household items & 59.34 & 0.02 & \\
& $(1.99)$ & $(0.00)$ & 9557 \\
Personal items & 142.82 & 0.02 & 8492 \\
& $(16.76)$ & $(0.00)$ & \\
& 267.33 & 0.10 & $(0.00)$ \\
\hline
\end{tabular}

Note: standard errors of the means and shares are reported in parentheses. The balance of expenditure was spent on rent and other items. ZAR, or simply, R, stands for South African rand.

\subsection{Decision-Making Power and Household Expenditure}

Table 4 compares mean monthly real per capita household expenditure between the treatment and control groups. Where the wife had greater financial decision-making power, expenditure was higher for household items (R111), education (R58), personal items (R17), healthcare (R13), utilities (R4), and non-food items (R82). In four cases, the mean expenditure was higher where the husband had greater financial decision-making power, namely, transport (R79), clothing (R12), insurance (R10), and food (R9). In only two instances, however, was the reported difference statistically significant $(p<0.10)$, and that was for monthly expenditure on education $(p<0.10)$ and on transport $(p<0.05)$.

Turning to the coarsened exact matching (CEM) results, a comparison was made between the unadjusted and unmatched versus the adjusted and matched sample treatment effect on the treated (SATT) (Table 5). Sample size retention in the CEM analysis, at $95.1 \%$, was relatively high and negated the one central limitation of CEM, namely that low retention negatively affects the precision with which treatment effects can be estimated (Guo et al. 2020). After matching, $L_{1}$, the global measure of imbalance, was reduced from 0.638 to approximately zero. Four expenditure categories reported statistically significant treatment effects on the treated for non-food (SATT $=143.12 ; p$-value $=0.059$ ), education $($ SATT $=90.49 ; p$-value $=0.012)$, insurance $($ SATT $=30.55 ; p$-value $=0.019)$, and clothing $($ SATT $=63.51 ; p$-value $=0.001)$. For these categories, couples where wives had greater decision-making power spent more in real per capita terms than couples where husbands had greater decision-making power. Compared to the MDM and PSM results 
(Appendix A), however, it was only the result for education that was statistically significant in all three sets of estimates.

Table 4. Monthly per capita household expenditure by decision-making power.

\begin{tabular}{ccccc}
\hline $\begin{array}{c}\text { Expenditure } \\
\text { Category }\end{array}$ & $\begin{array}{c}\text { Wife's } \\
\text { Decision-Making } \\
\text { Power Greater than } \\
\text { Husband }\end{array}$ & $\begin{array}{c}\text { Husband's } \\
\text { Decision-Making } \\
\text { Power Greater than } \\
\text { Wife }\end{array}$ & $\begin{array}{c}\boldsymbol{p} \text {-Value } \\
\text { Sample }(\boldsymbol{n})\end{array}$ \\
\hline Food & 480.31 & 489.93 & 0.438 & 7598 \\
Non-food & 1495.63 & 1413.77 & 0.350 & 7598 \\
Education & 330.51 & 272.03 & 0.095 & 1666 \\
Healthcare & 510.05 & 497.91 & 0.779 & 1716 \\
Utilities & 169.96 & 165.56 & 0.608 & 6172 \\
Insurance & 169.82 & 179.62 & 0.466 & 4680 \\
Transport & 476.77 & 555.22 & 0.030 & 3728 \\
Clothing & 255.39 & 267.23 & 0.492 & 1677 \\
Household items & 897.54 & 786.55 & 0.622 & 1245 \\
Personal items & 298.43 & 281.91 & 0.551 & 6057 \\
\hline
\end{tabular}

Table 5. Effect of decision-making power on monthly per capita household expenditure (SATT).

\begin{tabular}{|c|c|c|c|c|c|c|}
\hline \multirow[b]{2}{*}{$\begin{array}{l}\text { Expenditure } \\
\text { Category }\end{array}$} & \multicolumn{3}{|c|}{ A. Unadjusted and Unmatched } & \multicolumn{3}{|c|}{ B. Adjusted and Matched } \\
\hline & SATT (SE) & $\begin{array}{c}\text { t-Test } \\
(p \text {-Value) }\end{array}$ & Sample $(n)$ & SATT (SE) & $\begin{array}{c}t \text {-Test } \\
(p \text {-Value) }\end{array}$ & Sample $(n)$ \\
\hline Food & $\begin{array}{c}-9.622 \\
(12.376)\end{array}$ & $\begin{array}{l}-0.78 \\
(0.437)\end{array}$ & 7598 & $\begin{array}{c}14.072 \\
(11.440)\end{array}$ & $\begin{array}{c}1.23 \\
(0.219)\end{array}$ & 7142 \\
\hline Non-food & $\begin{array}{c}81.856 \\
(86.557)\end{array}$ & $\begin{array}{c}0.95 \\
(0.344)\end{array}$ & 7598 & $\begin{array}{l}143.125 \\
(75.912)\end{array}$ & $\begin{array}{c}1.89 \\
(0.059)\end{array}$ & 7.142 \\
\hline Education & $\begin{array}{c}92.424 \\
(30.794)\end{array}$ & $\begin{array}{c}3.00 \\
(<0.01)\end{array}$ & 7357 & $\begin{array}{c}90.495 \\
(36.220)\end{array}$ & $\begin{array}{c}2.50 \\
(0.012)\end{array}$ & 6920 \\
\hline Healthcare & $\begin{array}{c}61.488 \\
(39.518)\end{array}$ & $\begin{array}{c}1.56 \\
(0.120)\end{array}$ & 7244 & $\begin{array}{c}35.265 \\
(38.755)\end{array}$ & $\begin{array}{c}0.91 \\
(0.363)\end{array}$ & 6809 \\
\hline Utilities & $\begin{array}{l}21.462 \\
(8.425)\end{array}$ & $\begin{array}{c}2.55 \\
(0.011)\end{array}$ & 7037 & $\begin{array}{c}0.906 \\
(8.174)\end{array}$ & $\begin{array}{c}0.11 \\
(0.912)\end{array}$ & 6623 \\
\hline Insurance & $\begin{array}{c}65.094 \\
(11.824)\end{array}$ & $\begin{array}{c}5.50 \\
(<0.01)\end{array}$ & 7162 & $\begin{array}{c}30.557 \\
(13.075)\end{array}$ & $\begin{array}{c}2.34 \\
(0.019)\end{array}$ & 6732 \\
\hline Transport & $\begin{array}{c}120.29 \\
(34.784)\end{array}$ & $\begin{array}{c}3.46 \\
(<0.01)\end{array}$ & 7205 & $\begin{array}{c}23.126 \\
(33.123)\end{array}$ & $\begin{array}{c}0.70 \\
(0.485)\end{array}$ & 6770 \\
\hline Clothing & $\begin{array}{c}78.486 \\
(17.519)\end{array}$ & $\begin{array}{c}4.48 \\
(<0.01)\end{array}$ & 7360 & $\begin{array}{c}63.514 \\
(18.389)\end{array}$ & $\begin{array}{c}3.45 \\
(0.001)\end{array}$ & 6917 \\
\hline $\begin{array}{l}\text { Household } \\
\text { items }\end{array}$ & $\begin{array}{c}282.383 \\
(173.274)\end{array}$ & $\begin{array}{c}1.63 \\
(0.103)\end{array}$ & 7379 & $\begin{array}{c}187.501 \\
(156.150)\end{array}$ & $\begin{array}{c}1.20 \\
(0.230)\end{array}$ & 6936 \\
\hline Personal items & $\begin{array}{l}53.413 \\
(26.916)\end{array}$ & $\begin{array}{c}1.98 \\
(0.047)\end{array}$ & 6561 & $\begin{array}{l}36.324 \\
(24.942)\end{array}$ & $\begin{array}{c}1.46 \\
(0.145)\end{array}$ & 6172 \\
\hline$L_{1}$ & & & 0.638 & & & 0.000 \\
\hline
\end{tabular}

Note: results are based on coarsened exact matching. SATTs were estimated with a Tobit regression model adjusted for dependent ratios, household income, and survey round. Standard errors for SATT are reported in parentheses. Standard errors are heteroscedasticityconsistent (Abadie and Imbens 2006).

Pahl (1995), Dema-Moreno (2009), and Cantillon et al. (2016) documented the inequitable gender dynamics in financial organization and decision-making in couples. In reality, therefore, women may be empowered financially but still lack agency and autonomy. According to the results presented here, though, assigning greater financial decision-making power to women also holds the promise of improving household welfare in the longer term via its impact on resource allocations. As suggested by research synthesis, the empowerment of women has impacted positively not only on the wellbeing of women themselves but also on their children's education. School enrolment has been shown to be associated with women's decision-making autonomy in rural Mozambique (Luz and 
Agadjanian 2015) and Honduras (Hendrick and Marteleto 2017). These improvements would not be possible without the necessary resource allocations to these ends within the household economy. The empowerment of women with financial decision-making power, therefore, holds the promise of impacting positively on household expenditure on education, thus potentially realizing the benefits of investments in human capital (Doepke and Tertilt 2019). This result corroborates findings by Quisumbing and Maluccio (2003) in Bangladesh and South Africa, as well as evidence from Bulgaria (Felkey 2013) and Iran (Basu and Maitra 2020). However, women's decision-making agency and autonomy are important in their own right as a source of gender empowerment (Kabeer 1999) and as a development goal, as embodied in Agenda 2030's fifth Sustainable Development Goal (SDG) of gender equality.

It is necessary, however, to recognize that the decision-making question in this survey was posed with no clear distinction between high-level decisions on the allocation of resources and instrumental decisions regarding the management of the allocated resources (Lauer and Yodanis 2011; Skogrand et al. 2011; Mazzotta et al. 2019), or what Rosen and Granbois (1983) describe as decision and implementation tasks. Greater involvement of women in financial decision-making may reflect their involvement in the instrumental management of household resources and not in overall allocative control. This calls for household surveys with more carefully designed modules on decision-making, including measures such as the Relative Autonomy Index (RAI) of Vaz et al. (2016) and specific questions on the organization of household finances (Vogler 2005). In addition, decisionmaking by non-resident couples, a common phenomenon in many developing countries, cannot be investigated with the aid of this survey, thus calling for further research of both a qualitative and quantitative nature.

\section{Conclusions}

This study contributes to the analysis of intra-household decision-making and household expenditure using coarsened exact matching, an identification strategy not yet applied in studies of this nature. An important result reported in this study is that enhancing women's financial decision-making power is associated with higher monthly per capita household expenditure on some family-type public goods, in particular, education. Education is a critical component of human capital. High investment in children's education improves human capital in the economy. Education essentially facilitates knowledge acquisition and, thus, promotes participation in society and in the job market. Education can also facilitate the development of new technologies through knowledge sharing and transmission (Benhabib and Spiegel 2005). In relation to collective intra-household decision-making models, financial decision-making roles, therefore, are shown to represent important, higher-level "sharing rules" or "distributional factors" impacting more directly on resource allocation.

Author Contributions: Conceptualization: S.G. and F.B.; methodology: F.B. and S.G.; software: F.B. and S.G.; validation: S.G. and F.B.; formal analysis: F.B.; investigation: S.G.; writing—original draft preparation: S.G.; writing—review and editing: F.B. All authors have read and agreed to the published version of the manuscript.

Funding: This research received no external funding. The researchers used their institutions' (University of the Free State and University of the Witwatersrand) research funds for the article processing charge (APC).

Institutional Review Board Statement: This article uses secondary and anonymized data. The study was conducted according to the guidelines of the Declaration of Helsinki.

Informed Consent Statement: This article uses secondary and anonymized data. The SALDRU obtained consent from all participants. For the data available to the public, all personal information that would allow the identification of any person(s) described in the article has been removed.

Data Availability Statement: Data are available from the authors upon request. 
Acknowledgments: We would like to thank the SALDRU for making the National Income Dynamic Study (NIDS) survey data publicly available.

Conflicts of Interest: There are no conflicts of interest.

Appendix A

Table A1. Effect of decision-making power on monthly per capita household expenditure for MDM and PSM.

\begin{tabular}{|c|c|c|c|c|c|}
\hline \multirow{2}{*}{$\begin{array}{l}\text { Expenditure } \\
\text { Category }\end{array}$} & \multicolumn{2}{|c|}{$\begin{array}{l}\text { Mahalanobis Distance Matching } \\
\text { (MDM) }\end{array}$} & \multicolumn{2}{|c|}{$\begin{array}{l}\text { Propensity Score Mathing } \\
\text { (PSM) }\end{array}$} & \multirow{2}{*}{ Sample $(n)$} \\
\hline & ATT (SE) & $t$-Statistic & ATT (SE) & $z$-Statistic & \\
\hline Food & $\begin{array}{c}-9.960 \\
(10.731)\end{array}$ & -0.93 & $\begin{array}{c}-8.147 \\
(13.905)\end{array}$ & -0.59 & 7511 \\
\hline Non-food & $\begin{array}{l}119.462 \\
(71.901)\end{array}$ & 1.66 & $\begin{array}{l}119.128 \\
(87.356)\end{array}$ & 1.36 & 7511 \\
\hline Education & $\begin{array}{l}21.435 \\
(9.069)\end{array}$ & 2.36 & $\begin{array}{l}20.916 \\
(8.815)\end{array}$ & 2.37 & 7275 \\
\hline Healthcare & $\begin{array}{l}21.530 \\
(9.245)\end{array}$ & 2.33 & $\begin{array}{c}9.809 \\
(11.881)\end{array}$ & 0.83 & 7165 \\
\hline Utilities & $\begin{array}{c}9.002 \\
(6.934)\end{array}$ & 1.30 & $\begin{array}{c}-8.899 \\
(12.003)\end{array}$ & -0.74 & 6963 \\
\hline Insurance & $\begin{array}{l}10.707 \\
(9.269)\end{array}$ & 1.16 & $\begin{array}{c}10.944 \\
(11.989)\end{array}$ & 0.91 & 7081 \\
\hline Transport & $\begin{array}{c}11.992 \\
(18.616)\end{array}$ & 0.64 & $\begin{array}{c}0.665 \\
(24.642)\end{array}$ & 0.03 & 7121 \\
\hline Clothing & $\begin{array}{c}5.605 \\
(6.024)\end{array}$ & 0.93 & $\begin{array}{l}16.809 \\
(5.071)\end{array}$ & 3.31 & 7277 \\
\hline Household items & $\begin{array}{c}25.444 \\
(44.764)\end{array}$ & 0.57 & $\begin{array}{c}6.889 \\
(42.242)\end{array}$ & 0.16 & 7295 \\
\hline Personal items & $\begin{array}{c}14.861 \\
(26.005)\end{array}$ & 0.57 & $\begin{array}{c}30.068 \\
(23.054)\end{array}$ & 1.30 & 6490 \\
\hline
\end{tabular}

\section{Notes}

1 In the survey, household members are defined as follows: (i) you have lived under this "roof" or within the same compound/homestead/stand for at least 15 days during the last 12 months OR you arrived here in the last 15 days and this is now your usual residence AND (ii) when you are together you share food from a common source with other household members AND (iii) you contribute to or share in a common resource pool.

2 As the assignment of decision-making roles is based on both self-report and the report of others, there is room for disagreement between household members regarding a person's decision-making role. Further analysis into financial decision-making dynamics could focus on these disagreements, providing a much richer and nuanced picture. Such analysis, however, is beyond the scope of this paper, which adopted a simpler approach to the assignment of decision-making responsibility and power within couples.

3 The reference period in the household expenditure questions is the past 30 days. For some expenditure categories, particularly education, healthcare, and household items, consumption is more intermittent and occurs less frequently, hence the relatively low monthly expenditures on these items.

\section{References}

Abadie, Alberto, and Guido W. Imbens. 2006. Large sample properties of matching estimators for average treatment effects. Econometrica 74: 235-67. [CrossRef]

Ambler, Kate, Cheryl Doss, Caitlin Kieran, and Simone Passarelli. 2021. He says, she says: Spousal disagreement in survey measures of bargaining power. Economic Development and Cultural Change 69: 765-88. [CrossRef]

Baland, Jean-Marie, and Roberta Ziparo. 2018. Intra-household bargaining in poor countries. In Towards Gender Equity in Development. Edited by Siwan Anderson, Lori Beaman and Jean-Philippe Platteau. Oxford: Oxford University Press, pp. 69-96.

Baser, Onur. 2006. Too Much Ado about Propensity Score Models? Comparing Methods of Propensity Score Matching. Value in Health 9: 377-85. [CrossRef]

Basu, Bharati, and Pushkar Maitra. 2020. Intra-household bargaining power and household expenditure allocation: Evidence from Iran. Review of Development Economics 24: 606-27. [CrossRef] 
Benhabib, Jess, and Mark M. Spiegel. 2005. Human capital and technology diffusion. Handbook of Economic Growth 1: 935-66.

Bertocchi, Graziella, Marianna Brunetti, and Costanza Torricelli. 2014. Who holds the purse strings within the household? The determinants of intra-family decision making. Journal of Economic Behavior E Organization 101: 65-86.

Blackwell, Matthew, Stefano Iacus, Gary King, and Giuseppe Porro. 2010. cem: Coarsened exact matching in stata. Stata Journal 9: 524-46. [CrossRef]

Blumberg, Rae L., and Marion T. Coleman. 1989. A Theoretical Look at the Gender Balance of Power in the American Couple. Journal of Family Issues 10: 225-50. [CrossRef]

Bourguignon, Francois, Martin Browning, and Pierre-Andre Chiappori. 2009. Efficient intra-household allocations and distribution factors: Implications and identification. Review of Economic Studies 76: 503-28. [CrossRef]

Browning, Martin, and Pierre-Andre Chiappori. 1998. Efficient Intra-Household Allocations: A General Characterization and Empirical Tests. Econometrica 66: 1241-78. [CrossRef]

Browning, Martin, Pierre-Andre Chiappori, and Yoram Weiss. 2014. Economics of the Family. Cambridge: Cambridge University Press.

Cantillon, Sara, Bertrand Maître, and Dorothy Watson. 2016. Family Financial Management and Individual Deprivation. Journal of Family and Economic Issues 37: 461-73. [CrossRef]

Couprie, Hélène, Eugenio Peluso, and Alain Trannoy. 2010. Is Power More Evenly Balanced in Poor Households? Journal of Public Economics 94: 493-507. [CrossRef]

Dema-Moreno, Sandra. 2009. Behind the negotiations: Financial decision-making processes in Spanish dual-income couples. Feminist Economics 15: 27-56. [CrossRef]

Doepke, Matthias, and Michèle Tertilt. 2019. Does female empowerment promote economic development? Journal of Economic Growth 24: 309-43. [CrossRef]

Dosman, Donna, and Wiktor Adamowicz. 2006. Combining stated and revealed preference data to construct an empirical examination of intrahousehold bargaining. Review of the Economics of the Household 4: 15-34. [CrossRef]

Doss, Cheryl R. 2013. Intrahousehold Bargaining and Resource Allocation in Developing Countries. World Bank Research Observer 28: 52-78. [CrossRef]

Felkey, Amanda J. 2013. Husbands, Wives and the Peculiar Economics of Household Public Goods. European Journal of Development Research 25: 445-65. [CrossRef]

Fullerton, Birgit, Boris Pöhlmann, Robert Krohn, John L. Adams, Ferdinand M. Gerlach, and Antje Erler. 2016. The Comparison of Matching Methods Using Different Measures of Balance: Benefits and Risks Exemplified within a Study to Evaluate the Effects of German Disease Management Programs on Long-Term Outcomes of Patients with Type 2 Diabetes. Health Services Research 51: 1960-80. [CrossRef]

Gan, Li, and Victoria Vernon. 2003. Testing the Barten Model of Economics of Scale in Household Consumption: Toward Resolving a Paradox of Deaton and Paxson. Journal of Political Economy 111: 1361-77. [CrossRef]

Gummarson, Elizabeth, and Daniel Schneider. 2013. Eat, Drink, Man, Woman: Gender, Income Share and Household Expenditure in South Africa. Social Forces 91: 813-36. [CrossRef]

Guo, Shenyang, Mark Fraser, and Qi Chen. 2020. Propensity Score Analysis: Recent Debate and Discussion. Journal of the Society for Social Work and Research 11: 463-82. [CrossRef]

Hendrick, Emily, and Leticia Marteleto. 2017. Maternal Household Decision-Making Autonomy and Adolescent Education in Honduras. Population Research and Policy Review 36: 415-39. [CrossRef]

Himmelweit, Susan, Christina Santos, Almudena Sevilla, and Catherine Sofer. 2013. Sharing of Resources Within the Family and the Economics of Household Decision Making. Journal of Marriage and Family 75: 625-39. [CrossRef]

Iacus, Stefano M., Gary King, and Giuseppe Porro. 2012. Causal inference without balance checking: Coarsened exact matching. Political Analysis 20: 1-24. [CrossRef]

Iversen, Vegard. 2003. Intra-household inequality: A challenge for the capability approach? Feminist Economics 9: 93-105. [CrossRef]

Kabeer, Naila. 1999. Resources, Agency, Achievements: Reflections on the Measurement of Women's Empowerment. Development and Change 30: 435-64. [CrossRef]

Katz, Elizabeth. 1997. The Intra-Household Economics of Voice and Exit. Feminist Economics 3: 25-46. [CrossRef]

King, Gary, and Richard Nielsen. 2019. Why propensity scores should not be used for matching. Political Analysis 27: 435-54. [CrossRef]

Lauer, Sean R., and Carrie Yodanis. 2011. Individualized marriage and the integration of resources. Journal of Marriage and Family 73: 669-83. [CrossRef]

Leuven, Edwin, and Barbara Sianesi. 2003. PSMATCH2: Stata Module to Perform Full Mahalanobis and Propensity Score Matching, Common Support Graphing, and Covariate Imbalance Testing. Available online: http://ideas.repec.org/c/boc/bocode/s432001. html (accessed on 9 September 2016).

Luz, Luciana, and Victor Agadjanian. 2015. Women's decision-making autonomy and children's schooling in rural Mozambique. Demographic Research 32: 775-96. [CrossRef] [PubMed]

Maitra, Pushkar, and Ranjan Ray. 2006. Household expenditure patterns and resource pooling: Evidence of changes in post-apartheid South Africa. Review of Economics of the Household 4: 325-47. [CrossRef]

Mazzotta, Fernanda, Anna Papaccio, and Lavinia Parisi. 2019. Household management systems and women's decision making within the family in Europe. Feminist Economics 25: 126-58. [CrossRef] 
Menon, Martina, Federico Perali, and Luca Piccoli. 2018. Collective consumption: An application to the passive drinking effect. Review of Economics of the Household 16: 143-69. [CrossRef]

Mok, Thaiyoong P., Gillis Maclean, and Paul Dalziel. 2011. Household Size Economies: Malaysian Evidence. Economic Analysis E Policy 41: 203-23.

Opata, Patience I., Adaku B. Ezeibe, and Chikwuma O. Ume. 2020. Impact of women's share of income on household expenditure in southeast Nigeria. African Journal of Agricultural and Resource Economics 15: 51-64.

Pahl, Jan. 1995. His money, her money: Recent research on financial organisation in marriage. Journal of Economic Psychology 16: 361-76. [CrossRef]

Pan, Wei, and Haiyan Bai. 2018. Propensity score methods for causal inference: An overview. Behaviormetrika 45: 317-34. [CrossRef]

Phipps, Shelley A., and Peter S. Burton. 1998. What's Mine is Yours? The Influence of Male and Female Incomes on Patterns of Household Expenditure. Economica 65: 599-613. [CrossRef]

Quisumbing, Agnes R., and John A. Maluccio. 2003. Resources at Marriage and Intrahousehold Allocation: Evidence from Bangladesh, Ethiopia, Indonesia, and South Africa. Oxford Bulletin of Economics and Statistics 65: 283-327. [CrossRef]

Ripollone, John E., Krista F. Huybrechts, Kenneth J. Rothman, Ryan E. Ferguson, and Jessica M. Franklin. 2020. Evaluating the utility of coarsened exact matching for pharmacoepidemiology using real and simulated claims data. American Journal of Epidemiology 189: 613-22. [CrossRef]

Rosen, Dennis L., and Donald H. Granbois. 1983. Determinants of Role Structure in Family Financial Management. Journal of Consumer Research 10: 253-8. [CrossRef]

Schmeer, Kammi K. 2005. Married Women's Resource Position and Household Food Expenditures in Cebu, Philippines. Journal of Marriage and Family 67: 399-409. [CrossRef]

Skogrand, Linda, Alena C. Johnson, Amanda M. Horrocks, and John DeFrain. 2011. Financial management practices of couples with great marriages. Journal of Family and Economic Issues 32: 27-35. [CrossRef]

StataCorp. 2021. Stata Treatment-Effects Reference Manual. Available online: https:/ / www.stata.com/manuals/te.pdf (accessed on 9 August 2021).

Stuart, Elizabeth A. 2010. Matching Methods for Causal Inference: A Review and a Look Forward. Statistical Science 25: 1-21. [CrossRef] [PubMed]

Suen, Wing, William Chan, and Junsen Zhang. 2003. Marital transfer and intra-household allocation: A Nash-bargaining analysis. Journal of Economic Behavior E Organization 52: 133-46.

Vaz, Ana, Pierre Pratley, and Sabina Alkire. 2016. Measuring Women's Autonomy in Chad Using the Relative Autonomy Index. Feminist Economics 22: 264-94. [CrossRef]

Vogler, Carolyn. 2005. Cohabiting couples: Rethinking money in the household at the beginning of the twenty first century. Sociological Review 53: 1-29. [CrossRef] 